\title{
Between a rock and hard place: House-building in Brighton and Hove
}

\section{Samer Bagaeen}

In June 2013, Brighton and Hove City Council submitted Part One of their City Plan to the Secretary of State for independent examination. More than fifteen months on, elected councillors have not come to an agreement about the officers' proposed modifications in response to the Inspector's report and the council risks being forced to withdraw the plan. Suddenly, the city finds itself torn between the need to build new homes and the desire not to build them. How did it come to this?

In an article for the Daily Telegraph newspaper, Brandon Lewis MP (Lewis, 2014) suggested that Nimbyism was a thing of the past and that the 'government's radical new planning strategy' was the reason, as people now had more say in where new housing was built. Not so this paper will argue as the case of the small city of Brighton and Hove in East Sussex, wedged between the South Downs National Park and the English Channel, clearly demonstrates.

Mr. Lewis is of course right to make the assertion he does given that the most recent British Social Attitudes survey (DCLG, 2014a) shows that the number of people supporting the building of houses in their area has risen in the three years from 2010 to 2013. The survey shows that opposition to new homes fell substantially between 2010 and 2013, with 46 per cent of respondents saying they would oppose new homes being built in their local area in 2010, compared to 31 per cent in 2013. The proportion that was supportive of house building increased from 28 per cent in 2010 to 47 per cent in 2013. However, what the survey also shows is that although opposition fell across all age, tenure and income subgroups and among respondents living in different types of areas, home owners, particularly those living in small cities and towns and in rural areas, were still more likely to be opposed than renters and those living in large cities.

\section{Policy and public debate}

Changes to the planning system brought in with the Localism Act 2011 and National Planning Policy Framework in 2012 have shaped the way development needs are assessed, addressed and delivered across England over the course of this Parliament and are likely to have continued impacts well beyond the next General Election in 2015. As these words are being written, local Plans are being shaped, revised and updated within this context and these seek to guide development in each local planning authority area. Government measures introduced in 2013 were further meant to allow applications for major schemes to be made directly to the Planning Inspectorate where the local authority has been 'underperforming' in handling applications. The Planning Inspectorate was given responsibility under the Growth and Infrastructure Act 2013 to consider applications for major developments where a Local Planning Authority is designated by the Government to be in 'special measures'.

Even under this new policy, not much appears to have changed. According to a piece in The Planner, the first application to be considered under the government's planning performance measures was rejected (The Planner, 2014). This case is important, and what local planning authorities can or cannot do, as the two sides in the debate about house building battle it out in the national press to argue their case to the public and to the Government. Hill (2014) wrote 'Let's at least talk about building on London's greenbelt' in The Guardian. Webster (2014) wrote 'Snap a waste of space to 
solve house crisis' The Times. Hill flags a taboo amongst London's politicians that prevents them from even suggesting that homes could be built on greenbelt land. He quotes Paul Cheshire (Professor Emeritus of Economic Geography at LSE) who argued that "building on greenbelt land would only have to be very modest to provide more than enough land for housing for generations to come" and that "there is enough greenbelt land just within the confines of Greater London - 32,500 hectares - to build 1.6 million houses at average densities reducing pressure to build on playing fields" (Cheshire, 2014). Hill writes that opposition is both visceral and informed by a fear of being accused of going against nature by covering acres of it with bricks and mortar. The refuser front, he points out, includes politicians in the centre and on the left and the right, as we will see in Brighton and Hove later on. Webster on the other hand gives voice to the 'Waste of space' initiative by the pressure group the Campaign to Protect Rural England which asks people to pass on information on brownfield sites which can then be used to put pressure on the government to provide incentives for developers to target brownfields.

\section{The numbers game and the city plan}

Not even the brownfield land pot promoted by the Government in August 2014 (DCLG, 2014b) will be able to solve Brighton and Hove's woes as the city finds itself torn between the need to build new homes and the desire not to build them. In promoting this new pot, the Government anticipates that councils who bring forward brownfield land for development could benefit from a share of $f 5$ million to get work started on the new homes, potentially paving the way for planning permissions on up to 200,000 new homes across the country. Brownfield sites in Brighton and Hove are however a rare commodity as the city's 2011 Strategic Housing Land Availability Assessment (SHLAA), undertaken by GVA Grimley, found out ${ }^{1}$. This SHLAA identified 275 sites (most were occupied or in daily use) with a capacity of up to 7,425 homes in the city by 2025 including sites where 75 homes could be built on land occupied by a reservoir and land over-looking the mainline railway line into Brighton Station where 24 homes could be built.

Curiously for a town where universities contribute millions to the local economy (Oxford Economics, 2013), and going against officer recommendation, Imms (2014) notes how Brighton and Hove city councillors voted in June 2014 against a $£ 500$ million plan by the University of Sussex for student housing and academic buildings at the university's campus in Falmer. The plans would have seen room for 2,530 students on campus contributing to an expected 4,600 increase in students at the university by 2018. Imms points out how the size and breadth of the scheme was too much for councillors who felt the application could be broken down into smaller proposals. Councillors' objections focused around four themes:

- The negative impact on the amenities of the campus in terms of ecology through a loss of trees

- Concerns over the scale and height of the plans with fears it would create a "dense urban environment"

- The failure to demonstrate there would be no negative impact on the city's housing stock.

- The plan did not respect the composition of the campus as envisaged by Sir Basil Spence originally in the 1960s - when the campus was originally intended for 800 students! 
This decision to refuse permission represents a reversal of policy for the Green-run city whose leader, Councillor Bill Randall, was quoted in the daily Argus newspaper (see Ridgway, 2011) saying that "There are 3,500 homes in the city occupied by students. If we build more student housing then naturally that frees up homes for families".

The problem in 2014 is that urbanising the urban fringe, where the University of Sussex sits, has become a key battlefield ahead of the 2015 elections. Anti-housing and anti-development sentiment as articulated by Hill is therefore quite rife in Brighton and Hove. Earlier this year (2014), there was plenty of political opposition against a scheme for housing in Ovingdean village on the eastern fringe of the city ${ }^{2}$. In response to a proposal by Lightwood Property, based in Esher, Surrey, to build 112 homes on a greenfield site on the Meadow Vale area in Ovingdean (Figure 1), Simon Kirby, the Conservative MP for Brighton East, promised to press ministers to call in - or review - any planning application submitted to Brighton and Hove City Council to develop the site. As a sign of shifting attitudes on the part of the council's planners, the site was previously listed as 'undeliverable' in the 2011 SHLAA.

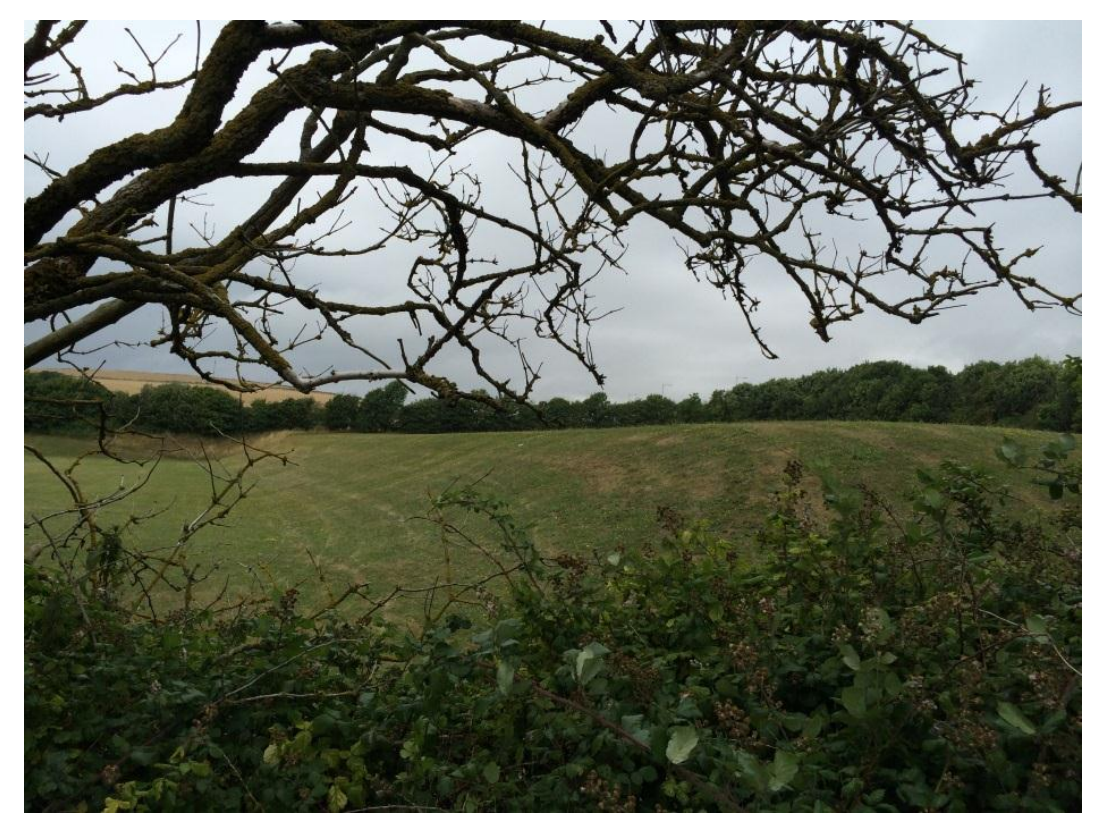

Figure 1: The Meadow Vale site (photograph by the author)

Mr. Kirby's view was that "People are rightly angry that the special village feel of Ovingdean, Rottingdean and Woodingdean could be compromised by this development" and suggested that the city council should be looking more closely at brownfield sites and infill sites across the city to deliver more housing before approving developments on valuable green land (Webster's and CPRE's arguments). The city's Labour politician and candidate for May 2015, Nancy Platts, agreed with Kirby's assessment and came out in support of the Save our Deans campaign ${ }^{3}$ set up by local residents to fight Lightwood's proposals for planning application number 2014/02589. Davy Jones, the Green Party candidate for Brighton Kemptown in 2015, also blogged about his opposition to the development (Jones, 2014). The reader should note that it is Green Party policy in Brighton and Hove to fight to repeal the NPPF and the city's Green Councillor Phelim McCafferty, chair of Planning successfully moved a motion at Brighton and Hove Council on 8 May opposing the NPPF. According to group leaflets, the Save our Deans campaign is trying to stop what it calls a high density housing 
development - 112 units - lowland chalk grassland Greenfield site and to make sure that a "precedent which could potentially open the floodgates to further development in the Deans" cannot go ahead. The Brighton and Hove council's own urban fringe assessment gave strong weight to the NPPF policy (at paragraphs 73 and 74) to protect existing open spaces and to the protection of the city's biodiversity resource. Weight was therefore given to 'local designations' on sites. The Meadow Vale site, and other sites in the city's urban fringe, are however not subject to any nationally recognised designations which would indicate that development may be restricted.

The local newsaper, The Argus, broke the story about the proposed development on the Meadow Vale in February 2014 (Walker, 2014) suggesting that 'a huge housing estate was being proposed on the edge of the South Downs National Park' immediately galvanising local opposition. The Meadow Vale site was inside the South Downs National Park until the boundary was changed in 2009. The project was proposed after the Government planning Inspector, Laura Graham, judged the Brighton and Hove City Plan to be unsound in part because "the starting point for analysis of the [urban fringe] sites has been the desire to resist development" (Graham, 2013).

In June 2013, Brighton and Hove City Council submitted Part One of their City Plan (2010 - 2030) to the Secretary of State for independent examination. Public hearings were held in October 2013 and on $13^{\text {th }}$ December 2013 the Inspector issued her initial conclusions on the Plan. She found that Brighton and Hove had met the duty to cooperate by seeking to engage positively with neighbouring authorities in the region but further work was required on matters of soundness, in particular around meeting housing needs and the assessment of sites in the city's urban fringe to ascertain their potential contribution towards meeting the city's needs. Even though the duty to cooperate legal test had been met, the expectation was that the Council would still be required to work collaboratively with other authorities to seek to improve housing provision given the identified levels of housing need in the city. This is because the Inspector, in her initial conclusions in December 2013, found that the City Council had not been able to meet its own housing need through its Local Development Plan and recommended a robust assessment of potential housing development sites in order to maximise the extent to which the City Council could meet housing need within its own borders and identify a further source of supply. Brighton and Hove City Council spent two years drawing up the City Plan which aimed to create 11,300 homes - thousands below the expected demand of 20,000 houses. However, the Inspector considered that the council had not done enough to reduce the level of shortfall between the housing target in the city plan (11,300 units) and objectively assessed housing needs $(20,000)^{4}$. Specifically, she noted, the council needed to look more carefully at the urban fringe for potential housing sites.

Matters took a turn for the worse in July 2014 when, in a letter from the Inspector to BHCC dated 21 July 2014, the Inspector wrote that if the Council was unable to agree to carry out public consultation on main modifications at its meeting in October 2014, she might need to conclude that the request made under section $20(7 \mathrm{C})$ has been implicitly withdrawn, as envisaged in paragraph 4.28 of the Inspectorate's Procedural Guidance. In these circumstances she would be unable to find the City Plan Part 1 sound and would expect the Council to withdraw the Plan. The reasons for the delay on the council's side were, as explained in a letter dated 17 July 2014 to the Inspector from the city's Local Development Team Manager, because the proposed main changes ('modifications') to the City Plan to Policy were not likely to receive the support of a majority of councillors at the 
Council's Resources Committee earlier in the month and were therefore deferred until October to allow further discussions between councillors to seek a consensus.

The ongoing City Plan examination cannot therefore be concluded within the anticipated timeframe and the City Plan cannot be adopted until this and other concerns are addressed through the modifications to the City Plan. The most significant requirement of the Inspector was for the council to more rigorously investigate opportunities for potential housing sites in the urban fringe in order for her to determine whether there is greater potential for the delivery of new housing from this source. The Inspector has made it clear that only then would she be in the position to consider whether the Plan could be found sound. As we can see in the transformation of the Meadow Vale site from 'undeliverable' in 2011 to potential site in 2014, these 'modifications' represent a major shift in policy in the City Plan - and will require a major 'culture' shift in attitudes for the city's elected councillors.

\section{Concluding thoughts}

The case of Brighton and Hove outlined here clearly reflects concerns noted in the Nathaniel Lichfield \& Partners insight document 'Positive Preparations: A review of housing targets and local plans post-NPPF' (NLP, 2014). This document suggests that progress on getting submitted plans found sound appears to have slowed with evidence and upward pressure on housing targets being the key factor with plans stalling due to the policy requirement to meet objectively assessed housing needs (ONAs).

On page 2, the study finds that since the National Planning Policy Framework (NPPF) was introduced in March 2012, 109 plans have been examined or submitted for examination outside London. Of these, just 40 (37\%) have been found sound and a quarter of these are subject to immediate or early review. In most cases the focus of the early review for these plans is to check that they meet objectively assessed needs for housing. Moreover, in the two years since the NPPF fifteen councils have withdrawn their Plans with the main reason for almost three quarters $(73 \%)$ of these being in relation to the provision of housing. The remaining 54 Plans are ongoing. However, almost half of these (48\%) have experienced delays and require further modifications to their original submitted plans, as is the case in Brighton and Hove. Of the 26 Plans that require modifications, 18 (69\%) of these specifically require more evidence of objectively assessed housing need.

The report found that one third of LPAs had to increase their submitted housing target in order to be found sound and although the Greater Brighton City Deal (DPMO, 2014) should deliver the enabling of sites to deliver up to 2,000 new homes over the medium-term, the lack of sites is proving a serious obstacle to achieving housing numbers. This in itself is a serious problem as a local authority in Worcestershire, Bromsgrove District Council, found out when it had its local plan hearing put on hold after the inspector concluded it could not proceed until further work on the evidence base for its housing numbers was complete (Early, 2014). The inspector, Michael Hetherington, had previously warned Bromsgrove over the local plan evidence base and has now disagreed with the methodology used to come up with the housing numbers.

If the assumption that Brighton and Hove councillors could not agree the city plan modifications because of a desire to protect the urban fringe from development is accurate (one councillor suggested redeveloping 100 year old housing estates with huge gardens as an alternative to chipping 
away at the urban fringe), then they must have a case to answer if the city plan is declared unsound and should be taken to task. What a city like Brighton and Hove needs is strong political leadership that can deliver housing where it is possible and needed.

Stunned officials and frightened councillors booed and hissed by members of the public had not been seen since the battles over building supermarkets in the Scottish highlands died down (Ross, 2009). In a blog, Councillor Tessa Coombes comments on her time as a Bristol city councillor sitting on the planning committee ${ }^{5}$ noting how she "often felt powerless to change things and unable to take the right decisions because she "was hampered by a system that favours the private developer" but suggesting that as a councillor she was "often too cautious, too afraid to take those difficult decisions... and not brave enough to show real leadership when it was needed".

Councillors in Brighton and Hove need to understand that the benefit of having an adopted City Plan is that it will carry full weight in decision-making. Applications for housing development will be assessed against the adopted City Plan housing target $(13,225)$ rather than the city's full objectively assessed housing need figure of 24,000 homes (the top end of the range). This will ensure that the city's aspirations for key sites/strategic allocations can be realised. Much needed employment sites and privately owned green spaces within the urban area could then be better protected from inappropriate development. An adopted City Plan and a published Urban Fringe Assessment Study with 31 hectares (out of 400 reviewed, $7.5 \%$ ) in the urban fringe found suitable for development can be used to resist speculative development proposals on the $92.5 \%$ of the urban fringe that was found not to have housing potential.

\section{Samer Bagaeen}

\section{University of Brighton Planning School}

\section{samer.bagaeen@uclmail.net}


Cheshire, P. (2014) 'Turning houses into gold: the failure of British planning', http://blogs.Ise.ac.uk/politicsandpolicy/turning-houses-into-gold-the-failure-of-british-planning/ accessed on 1 September 2014

DCLG (2014a) Public attitudes to new house building: Findings from the 2013 British Social Attitudes Survey, July 2014, Department for Communities and Local Government

DCLG (2014b) 'f5 million fund will unlock 100 brownfield sites for new homes', https://www.gov.uk/government/news/5-million-fund-will-unlock-100-brownfield-sites-for-new-homes accessed on 1 September 2014.

DPMO (2014) City Deal: Greater Brighton, Policy Paper, Deputy Prime Minister's Office, https://www.gov.uk/government/uploads/system/uploads/attachment data/file/288903/Greater Brighton C ity Deal.pdf accessed on 1 September 2014.

Early, C. (2014) 'Worcestershire local plan hearing put on hold over housing numbers', in http://www.planningresource.co.uk/article/1307017/worcestershire-local-plan-hearing-put-hold-housingnumbers accessed on 1 September 2014.

Graham, L. (2013) Letter to the council dated 13 December 2013 http://www.brighton-

hove.gov.uk/sites/brighton-hove.gov.uk/files/ID-21\%20Letter\%20to\%20council\%20Dec\%2013.pdf accessed on 1 September 2014

Hill, D. (2014) 'Let's at least talk about building on London's greenbelt', in the Guardian, Dave Hill's London Blog, 21 July 2014, http://www.theguardian.com/uk-news/davehillblog/2014/jul/21/lets-at-least-talk-aboutbuilding-on-londons-greenbelt accessed on 1 September 2014

Imms, A. (2014) 'Back to the drawing board for the University of Sussex', in The Argus, 25 June 2014, http://www.theargus.co.uk/news/11300443.University of Sussex student expansion plans fall through/ accessed on 1 September 2014

Jones, D. (2014) Meadow Vale - the plot thickens! http://www.davyjones4kemptown.org.uk/meadow-valeplot-thickens/ accessed on 1 September 2014.

Lewis, B. (2014) 'More people want more homes after our planning reforms', in The Daily Telegraph, 25 July 2014

NLP (2014) Positive preparations: A review of housing targets and local plans. March 2014 http://nlpplanning.com/PositivePreparations.pdf accessed on 1 September 2014.

Oxford Economics (2013) The economic impact of the University of Sussex, Oxford Economics

The Planner (2014) http://www.theplanner.co.uk/news/first-\%E2\%80\%98special-measures\%E2\%80\%99application-determined accessed on 30 July 2014

Ridgway, T. (2011) 'Prising open a cramped city', in The Argus, 25 May 2011

Ross, D. (2009) Store wars: fears over intimidation of councillors by 'people power' protests, in the Herald Scotland on 12 March 2009 http://www.heraldscotland.com/store-wars-fears-over-intimidation-ofcouncillors-by-people-power-protests-1.904819 accessed on 1 September 2014. 
Walker, E. (2014) 'Revealed: Secret plans to squeeze hundreds of homes on green land between two Brighton villages'

http://m.theargus.co.uk/news/11038779.Revealed Secret plans to squeeze hundreds of homes on gree n land between two Brighton villages/accessed on 1 September 2014.

Webster, B. (2014) 'Snap a waste of space to solve house crisis', in The Times, 30 July 2014, http://www.thetimes.co.uk/tto/environment/article4153773.ece accessed on 1 September 2014

\footnotetext{
${ }^{1}$ http://ww3.brighton-hove.gov.uk/index.cfm?request=c1250334\&node=20576 accessed on 8 August 2014.

${ }^{2}$ Brighton MP speaks out against proposed housing estate in Ovingdean http://thelatest.co.uk/brighton/2014/04/21/brighton-mp-speaks-out-against-proposed-housing-estate-inovingdean/ accessed on 1 September 2014.

${ }^{3}$ Save Our Deans www.saveourdeans.co.uk accessed on 1 September 2014.

${ }^{4}$ The current figures for Brighton and Hove's objectively assessed housing needs (OAN) based on updated 2011 ONS projects is 18,000-24,000 new homes over the plan period. The city can only deliver 13,225 new homes on key delivery sites and on sites across the rest of the city.

${ }^{5}$ http://tessacoombes.wordpress.com/2014/07/30/on-being-a-councillor/accessed on 1 September 2014.
} 